\title{
The Influence of Diabetic Foot Exercise on Sugar Levels In Type 2 Diabetes Mellitus Patients at Tanjung Buntung Public Health Center 2018
}

\author{
Rizki Sari Utami Muchtar ${ }^{1}$, Indah Triyani Dingin ${ }^{2}$ \\ ${ }^{1,2}$ Nursing, STIKes Awal Bros Batam, Indonesia \\ ${ }^{1}$ sariutami0784@gmail.com, ${ }^{2}$ indah.triyani@gmail.com
}

\begin{abstract}
\section{Keyword:}

Diabetes Mellitus;

Sugar Level;

Diabetic Foot Exercise.

Diabetes is a chronic disease that occurs either when the pancreas does not produce insulin or when the body is not effective enough in producing insulin. The International Diabates Federation (IDF) shows that the number of people who suffer diabetes in Indonesia is estimated at 10 million and half seventh rank highest in the world, Indonesia is the 4th country with the highest prevalence of diabetes in the world after India, China and the United States. The phenomenon found in the Tanjung Buntung Public Health Center working area in 2017 was 420 of them, 206 men and 214 people. This study aims to determine the influence of diabetic foot gymnastics on blood sugar levels with the research design using the Quasi experimental method with pretest and posttest without control research method, by sample collection using total sampling the sample of 20 respondents. The statistical test in this study uses the Paired T-Test which is tested first in the Shapiro-Wilk normality test. The results of it study indicate a decrease of 196.85 with a value of $\rho$-value of 0.000 or $>$ 0.05 . obtained a decrease average in blood sugar levels before diabetic foot exercises $239.60 \mathrm{mg} / \mathrm{dL}$ with poor criteria and after exercise $196.85 \mathrm{mg} /$ $\mathrm{dL}$ with moderate criteria. Therefore it can be concluded that there is the influence of diabetic foot exercise on blood sugar levels in type $2 \mathrm{DM}$ patients. Advice from researchers is expected to always be held diabetic foot exercise ini Tanjung Buntung's health center to reduce blood sugar levels in patient with type 2 diabetesmellitus.
\end{abstract}

\author{
Article History: \\ Received: 05-02-2018 \\ Revised : 20-04-2018 \\ Accepted: 28-04-2018 \\ Online : 30-04-2018

\section{A. INTRODUCTION}

Diabetes is a chronic disease that occurs either when the pancreas does not produce insulin or when the body is not sufficiently effective in producing insulin. Diabetes hormone is a chronic disease that occurs either when the pancreas does not produce insulin or when the body is not sufficiently effective in producing insulin. The hormone regulating insulin is a blood sugar Hyperglycaemia. The effect of not being loose in diabetes leads to damage to the body's system, especially nerves and blood vessels. In the year 2014, 8.5\% of adults suffer from diabetes (WHO, 2017).

The pain and mortality rate of diabetes mellitus is increasing annually. WHO even predicts diabetes mellitus sufferers will increase up to 21.3 million in the year 2030. Sample Registration 
Survey 2014 expressed diabetes to be the number three killer in Indonesia, while the International Diabates Federation (IDF) data shows, the number of diabetics in Indonesia is estimated at 10 million and ranks the seventh highest in the world. The prevalence of diabetes in Indonesia tends to increase from 5.7\% in 2007, becoming 6.9\% year 2013. As the Ministry of Health (Kemenkes) released, 2/3 Clinic (a designation for people of Diabates) in Indonesia does not know himself to have diabetes. This deadly disease is still a serious problem of the world, including Indonesia. Indonesia is the 4th country with the highest prevalence of diabetes in the world after India, China, and the United States. Even the number of diabetic-lifters continues to increase year after year. Uncontrolled Diabetes mellitus can cause various complications.

There are two complications of DM, acute (short-term) complications, and chronic (longterm) complications. Acute complications consist of diabetic ketoacidosis (KAD), non-toxic hyperosmolar (HNK), and hypoglycemia. In chronic complications can result in the occurrence of macrongiopathy which is about large blood vessels and the most common microngiopathy of one of them is diabetic ulcer. Diabetic ulcer is an open wound on the skin layer into the dermis. These complications can occur due to hyperglycemia and neuropathy resulting in a variety of changes in the skin and muscles, resulting in the imbalances of pressure distribution on the soles of the feet and further ease the occurrence of ulcers. (Palimbunga T M, Rataq B T, 2017) Examples of physical exercise or exercise are recommended by one of them is diabetic foot gymnastics. Diabetic Foot Gymnastics is recommended with moderate intensity (60-70 maximum heart rate), duration 30-60 minutes, with a frequency of 2-3 times per week and no more than 2 consecutive days do not perform diabetic foot gymnastics. (Tanto, Liwang, Hanifan, \& Pradipta, 2014) Physical exercise will cause an increase in blood flow, it will be more open capillary mesh so that more available insulin receptors and receptors become more active which will affect the reduction of blood glucose in diabetic patients. What distinguishes diabetic foot gymnastics with diabetic gymnastics is that diabetic foot gymnastics is one of the physical activities that is routinely recommended because it is hoped that there are frequent complications in the feet of patients suffering from diabetes mellitus such as: unhealed infections. (Syamsiah, 2011)

Diabetic Foot Gymnastics benefits improve blood circulation, strengthen the small muscles

of the leg, and prevent the occurrence of leg deformity increases the strength of the calf muscles, thigh muscles, overcoming the limitation of joint movement, while the benefits of diabetic gymnastics is controlling blood sugar, especially in type 2 DM that follow regular exercise. This is due to the cells can more respond to insulin and appropriately take glucose from the blood.

To inhibit and improve the risk factors of cardiovascular disease that many occur in patients with DM is a dangerous vascular disease that is coronary heart disease (CHD), stroke, peripheral vascular disease. Optimal exercise arrangement and DM diet in overweight (obese) people can lose weight. (Nendrastuti, IP Paru FK Unair, Soetomo Surabaya, Bag, \& Kardiologi Unair, 2010)

Based on the data researchers get from the Batam City Health office that the prevalence of Diabetes mellitus type 2 disease in the city of Batam annually found a new case that suffers from type 2 Diabetes mellitus. From January to December 2017, a new case of 420 patients with type 2 DM are 206 and female 214. (Dinas Kesehatan Provinsi Riau, 2015) From this data can be concluded that the sufferer of type 2 diabetes will continue to increase annually, if we can not prevent early, it will cause complications. (Indarti \& Palupi, 2018)

Based on the results of preliminary study that researchers did on 09 April 2018 in Tanjung Buntung Puskesmas, from the results of researchers conducted on 09 April from the results of interviews to 6 sufferers of diabetes mellitus 5 of them do not know of the diabetic foot gymnastics for blood sugar levels, they only do gymnastics such as physical fitness gymnastics, healthy gymnastics every month, sufferers also only reduce foods that contain sugar such as rice and there are also and most of them are also doing sports but like a morning run and even there are patients who do not at all exercise even reduce the consumption of sugar and from the examination results of blood sugar levels of diabetes mellitus sufferers have blood sugar levels > 220 mg/dL. (Sari, Kusumawati, Saleh, Kustiawan, \& Sukartingsih, 2018) 
Based on the background that researchers Described above diabetic foot gymnastics11 minutes per week can beReduce and prevent complications Diabetes mellitus. Therefore, researchers Interested in conducting research "The effect of diabetic foot gymnastics on Blood sugar levels in diabetic patients Type 2 in Tanjung Buntung health care ".

\section{B. METHODS}

The type of research used in this research is to use the Quasi Experiment Research Method (pseudo experiment) using the Pre Test and Post Test Without Control method. This research is a research that only intervene in one group without comparison groups. (Nursalam, 2017) The effectiveness of treatment assessed by comparing the pre-test results with post-test, pre-test before the intervention performed, after the measurement before giving intervention then given intervention 4 times/week for 2 weeks, after that the measurement is done again and after getting the results then compare pre-test results with the results of post test.

\section{RESULT AND DISCUSSION}

Table 1. Characteristics of the respondents DM Tipe2 based on the age of Puskesmas Tanjung Buntung 2018

\begin{tabular}{cccc}
\hline Gender & Age & Frequency & (\%) \\
\hline Male & Adult & 3 & 15 \\
Female & Midle Age & 17 & 85 \\
\hline Total & & 20 & 100 \\
\hline
\end{tabular}

According to Table 1 above, it is known that the greatest percentage of type $2 \mathrm{DM}$ is the late adult is the average of 35-45th.

Tabel 2. Characteristics of respondents based Sex of DM sufferer Tipe2 in Tanjung Buntung Puskesmas 2018

\begin{tabular}{cccc}
\hline Gender & Age & Frequency & (\%) \\
\hline Male & Adult & 10 & 50 \\
Female & Midle Age & 8 & 40 \\
& Elderly & 2 & 10 \\
\hline Total & & 20 & 100 \\
\hline
\end{tabular}

Based on the Table 2 explained that almost entirely of patients DM Tipe2 in Tanjung Buntung puskesmas year 2018 is woman is $85 \%$.

Table 3. Characteristics of respondents based on the level of education DM Tipe2 in Tanjung Buntung year 2018

\begin{tabular}{ccc}
\hline Education & Frequenc & $\mathbf{( \% )}$ \\
& y & \\
\hline SMP & 4 & 20 \\
SMA & 13 & 65 \\
S1 & 3 & 15 \\
\hline Total & 20 & 100 \\
\hline
\end{tabular}




\section{4 | IJECA (International Journal of Education and Curriculum Application)}

Vol. 1, No. 1, April 2018, pp. 1-6

Based on Table 3, you get the result that the education Respondengreater high school graduates are $65 \%$.

Table 4. Characteristics of patients with DM Tipe2 based on employment in Tanjung Buntung Puskesmas year 2018

\begin{tabular}{ccc}
\hline Job & Frequenc & (\%) \\
& $\mathbf{y}$ & \\
\hline Working & 4 & 20 \\
Not Working & 16 & 80 \\
\hline Total & 20 & 100 \\
\hline
\end{tabular}

Based on Table 4 in the results of the result of the respondents characteristics based on the work obtained by the results of people with DM type 2 more does not work due to the gender characteristics of more women or mothers who are domestic workers compared to the foreign work of $80 \%$.

Table 5. Average distribution of blood glucose levels prior to gymnastics feet of diabetic

\begin{tabular}{|l|c|}
\hline \multicolumn{1}{|c|}{ Variabel } & Kadar Gula Darah \\
\hline $\begin{array}{l}\text { Before diabetic foot } \\
\text { Gymnastic }\end{array}$ & $238.00 \mathrm{mg} / \mathrm{dL}$ \\
\hline
\end{tabular}

Based on Table 5 analysis results showed that the average score of blood sugar levels before the exercise of DM is $238.00 \mathrm{mg} / \mathrm{dL}$.

Table 6. Average distribution of blood glucose levels after diabetic foot gymnastics

\begin{tabular}{|c|c|}
\hline Variabel & Kadar Gula Darah \\
\hline $\begin{array}{c}\text { After diabetic } \\
\text { foot } \\
\text { Gymnastic }\end{array}$ & $206.00 \mathrm{mg} / \mathrm{dL}$ \\
\hline
\end{tabular}

According to Table 6 The results of the analysis showed that the average score of blood sugar decline after the exercise of DM gymnastics is $206.00 \mathrm{mg} / \mathrm{dL}$.

Table 7. The average difference in blood glucose levels in the influence of diabetic foot before and after in patients with DM type 2

\begin{tabular}{|l|c|c|c|c|}
\hline \multicolumn{1}{|c|}{ Variabel } & $\mathbf{n}$ & Mean & SD & $\boldsymbol{\rho}$-Value \\
\hline Before & 20 & $\begin{array}{r}238.00 \\
\mathrm{mg} / \mathrm{dl}\end{array}$ & 17.862 & 0.000 \\
\hline After & 20 & $\begin{array}{c}206.00 \\
\mathrm{mg} / \mathrm{dl}\end{array}$ & 6.316 & \\
\hline
\end{tabular}

Based on Table 7 in the results of the average score of blood sugar prior to the administration of the diabetic foot gymnastics is $238.00 \mathrm{mg} / \mathrm{dL}$ and after diabetes is given $206.00 \mathrm{mg} / \mathrm{dL}$ in the Get average reduction in blood glucose levels is $32 \mathrm{mg} / \mathrm{dl}$. Further analysis results obtained $\rho$-value of 0.000 . With a numerical significance of 0.05 which means that there is a difference between the average decrease in blood glucose before and after the diabetic foot. 
Based on the results of research that has been done in Table 3 of 20 respondents are known to average decrease in blood glucose levels before the use of diabetic gymnasticsis 238.00 $\mathrm{mg} / \mathrm{dl}$ and the influence after which the diabetes gymnastics is $206.00 \mathrm{mg} / \mathrm{dl}$. So that the average reduction in blood glucose levels to the influence of diabetes mellitus is an increase in the amount. From the results Bivariat test with 32 using T-Test obtained $\rho$-value $0.000<0.05$ thus Ho rejected. So there is a significant difference in the average results of blood sugar levels on the effect of diabetic foot gymnastics in patients with DM type 2 in Tanjung Buntung Healthin 2018.

After the study there is a decrease in blood sugar levels but not reaching normal blood sugar levels, because there are other factors that can lower blood sugar if it is joined with diabetic foot gymnastics such as, diet and stress settings in diabetics. This research is a study comparing blood sugar levels before and after, and knowing the presence of diabetic foot gymnastics influence on blood sugar levels in one intervention group. From the results of research that has been done before the exercise of dietictic foot gymnastics on the average blood sugar levels of respondents have high sugar levels (hyperglycemia).

This is in line with what is conveyed by Suddarth (Brunner \& Suddarth, 2013) stating that the age factor that the risk of suffering from Type $2 \mathrm{DM}$ is over 30 years of age, this is because a change starts from the cell level, then continues at the network level and finally at the level of the organ that can affect homeostatis. After a person reaches the age of 30 years, blood glucose levels rise $1-2 \mathrm{mg} \%$ each year during fasting and will rise $6-13 \%$ at 2 hours after meals, based on the fact that age is a major factor in the incidence of diabetes relevance as well as impaired glucose tolerance.

Reduction in blood sugar levels in patients with diabetes mellitus type 2 is performed "Diabetes mellitus" counseling and diabetic foot gymnastics, as for the material given to help lower blood sugar levels and control the blood sugar and diabetic foot gymnastics levels. At the time of delivery of the counseling is done by the method of lecture and question and answer with the two-way communication conducted by researchers in hopes of helping to control and normalize blood sugar levels. (Sukesi, 2017).

\section{CONCLUSION AND SUGGESTIONS}

The characteristics of respondents based on age, is the end of the adult age range of 35-46 years (50\%), and more suffered by women or housewives from 20 Reponden gained 17 female gender (85\%), from the average education level of high school/equivalent (65\%) And the average is no longer working $(80 \%)$. The value of blood sugar levels before the average diabetic foot gymnastics obtained results of $238.00 \mathrm{mg} / \mathrm{dL}$. The value of blood sugar levels after the average diabetic foot gymnastics obtained results of $206.00 \mathrm{mg} / \mathrm{dL}$. After the study, there is a difference in the average blood sugar level before the diabetic foot gymnastics with the average blood sugar level after diabetic foot gymnastics ( $\rho$-value:0.000).

\section{ACKNOWLEDGEMENT}

Thank you to the respondents and puskesmas who have given the opportunity to be a research place as one of the supporting facilities. Thank to STIKes Awal Bros Batam who has been supporting the progress of this research so it can be a source to the fore in advancing science in the field of health. 


\section{6 | IJECA (International Journal of Education and Curriculum Application)}

Vol. 1, No. 1, April 2018, pp. 1-6

\section{REFERENCES}

Brunner \& Suddarth. (2013). Keperawatan Medikal-Bedah Brunner \& Suddarth. In Keperawatan MedikalBedah Brunner \& Suddarth (pp. 190-192). https://doi.org/10.1116/1.578204

Dinas Kesehatan Provinsi Riau. (2015). Profil Kesehatan Provinsi Riau 2015. Profil Kesehatan Riau 2015, 73-74. Retrieved https://www.depkes.go.id/resources/download/profil/PROFIL_KES_PROVINSI_2015/04_Riau_201 5.pdf

Indarti, E. T., \& Palupi, H. (2018). Senam Kaki Lebih Efektif Meningkatkan Sirkulasi Darah Ke Kaki Dibanding Penurunan Kadar Glukosa Pada Penderita Diabetes Mellitus Di Wilayah Kerja Puskesmas Rejoso. Jurnal Ilmiah Keperawatan (Scientific Journal of Nursing), 4(2), 141-147. https://doi.org/10.33023/jikep.v4i2.193

Nendrastuti, H., IP Paru FK Unair, P. I., Soetomo Surabaya, R., Bag, S., \& Kardiologi Unair, S. F. (2010). Edema Paru Akut Kardiogenik Dan Non Kardiogenik. Majalah Kedokteran Respirasi, 1(3), 2010. Retrieved from http://journal.unair.ac.id/download-fullpapers-MKR Vol1 No 3 - 2 Abs.pdf

Nursalam. (2017). Metodologi Penelitian Ilmu Keperawatan. In Salemba Medika.

Palimbunga T M, Rataq B T, K. W. P. J. (2017). Faktor-Faktor yang berhubungan dengan Kejadian Diabetes Melitus Tipe 2 di RSU GMIM Pancaran Kasih Manado. FKM Unsrat Manado, 1-11.

Sari, Y. P., Kusumawati, E., Saleh, C., Kustiawan, W., \& Sukartingsih, S. (2018). Effect of sucrose and plant growth regulators on callogenesis and preliminary secondary metabolic of different explant $\begin{array}{llll}\text { Myrmecodia tuberosa. } & \text { Nusantara }\end{array}$ https://doi.org/10.13057/nusbiosci/n100309

Sukesi, N. (2017). Pengaruh Senam Kaki Terhadap Kadar Gula Darah Pada Pasien Dengan Diabetes Melitus. Jurnal Ilmu Dan Teknologi Kesehatan, 8(1). https://doi.org/10.33666/jitk.v8i1.50

Syamsiah, N. (2011). Faktor Faktor yang Berhubungan dengan Kepatuhan Pasien CKD yang Menjalani Hemodialisa di RSPAU Dr Esnawan Antariksa Halim Perdana Kusuma Jakarta.

Tanto, C., Liwang, F., Hanifan, S., \& Pradipta, E. A. (2014). Kapita Selekta Kedokteran Edisi IV. In Jakarta : Media Aesculapius. https://doi.org/10.22146/buletinpsikologi.25163

WHO. (2017). DIABETES INFOGRAFIA. Diabetes, 1. 